\title{
EFEKTIVITAS MEDIA PROMOSI PADA PRODUK SANDWICH GORENG MEREK ROYAL SANDWICH
}

\author{
Laila Afifah, Mudatsir Najamuddin* dan Bintan Humaeira
}

\begin{abstract}
ABSTRAK
Pemasaran adalah tonggak dalam pertanian, karena tanpa pemasaran,produk yang sudah dihasilkan sulit untuk dijual. Pemasaran bukan saja suatu metode untuk menjual produk sebanyak-banyaknya hingga mendapatkan keuntungan, tetapi juga salah satu cara sehingga produk yang dihasilkan mampu bertahan di pasaran. Perusahaan juga perlu mengkomunikasikan produk dan perusahaannya kepada para pelanggan, apalagi dalam situasi persaingan yang ketat. Keberhasilan pemasaran salah satunya dipengaruhi oleh promosi. Banyak produk yang tidak berhasil masuk pasar karena kegagalan promosi, walaupun dari segi kualitas tidak kalah dengan produk-produk lain (Simamora, 2003:284). Program promosi yang saat ini digemari oleh para pengusaha khususnya perusahaan dengan anggaran (budget) minim adalah dengan menggunakan media sosial sebagai alat untuk mempromosikan produknya. Salah satu perusahaan yang menggunakan media sosial sebagai alat untuk mempromosikan produknya adalah Royal Sandwich. Royal Sandwich merupakan salah satu UKM (Usaha Kecil Menengah) dibidang makanan beku (frozen food). Tujuan dari penelitian ini adalah: 1) Mengetahui macam-macam promosi yang dilakukan oleh Royal Sandwich, 2) Menganalisis efektivitas media promosi produk sandwich goreng merek Royal Sandwich berdasarkan dampak komunikasi, dan 3) Menganalisis efektivitas media promosi produk sandwich goreng merek Royal Sandwich berdasarkan dampak penjualan.
\end{abstract}

Kata kunci: pemasaran, promosi, convenience food, penjualan, UKM

\begin{abstract}
Marketing is a significant point in agriculture. Without marketing, products that have been resulted may be difficult to sale. Marketing is not just a method to sell products as many as possible for benefits, but it is also the way to keep the existence of produced products on the market. The company also needs to communicate the product and the company itself to the customers, especially in the situation of fierce competition. One of the marketing successes is influenced by the promotions. Many products are not successful in the market because of the promotions failure although in terms of quality are well-established if compared with the other products (simamora, 2003: 284). Promotion program that currently favored by business is by using social media as a way to promote their products especially in companies with low budget. One of companies that uses social media to promote the products is Royal Sandwich. Royal Sandwich is one of the UKM (small and medium enterprises) in the field of convenience food. The aims of this study are: 1) Recognizing various promotion conducted by the Royal Sandwich. 2) Analyzing the effectiveness of promotion media of the fried
\end{abstract}


sandwich product by Royal Sandwich based on the impact of communication. 3) Analyzing the effectiveness of promotion media of the fried sandwich product by Royal Sandwich based on the impact of sale.

Keywords: Marketing, promotion, convenience food, sale, small and medium entreprises 


\section{PENDAHULUAN}

Agribisnis merupakan keseluruhan operasi yang terkait dengan aktivitas untuk menghasilkan, mendistribusikan input produksi, aktivitas untuk produksi usahatani, serta pengolahan dan pemasaran (Tjakrawerdaya dalam Siagian,2003:1). Aktivitas agribisnis tidak lagi sekedar berorientasi pada produksi semata yaitu pemenuhan kebutuhan masyarakat pedesaan, tetapi juga dalam rangka memperoleh nilai tambah yang lebih besar, sehingga kegiatan off-farm seperti agroindustri dan pemasaran menjadi sangat penting (Siagian, 2003:2). Pemasaran adalah tonggak dalam pertanian, karena tanpa pemasaran, produk yang sudah dihasilkan sulit untuk dijual. Pemasaran bukan saja suatu metode untuk menjual produk sebanyak-banyaknya hingga mendapatkan keuntungan, tetapi juga salah satu cara sehingga produk yang mereka produksi mampu bertahan dalam benak konsumen.

Menurut Tjiptono dkk (2008:22) konsep pemasaran merupakan kunci untuk mewujudkan tujuan organisasi yang terletak pada kemampuan organisasi dalam menciptakan, memberikan, dan mengkomunikasikan nilai pelanggan kepada pasar sasarannya secara lebih efektif dibandinkan pesaing. Dalam pemasaran, kita tidak cukup hanya menciptakan produk yang baik, menetapkan harga yang menarik, dan membuat produk tersedia bagi pelanggan. Perusahaan juga perlu mengkomunikasikan produk dan perusahaan kepada para pelanggannya, apalagi dalam situasi persaingan yang ketat. Keberhasilan pemasaran salah satunya dipengaruhi oleh promosi. Banyak produk yang tidak berhasil masuk pasar karena kegagalan promosi walaupun dari segi kualitas tidak kalah dengan produkproduk lain (Simamora, 2003:284).
Salah satu perusahaan yang menggunakan media sosial sebagai alat untuk mempromosikan produknya adalah Royal Sandwich. Royal Sandwich merupakansalah satu UKM (Usaha Kecil Menengah) dibidang makanan beku (frozen food) Produk yang mereka pasarkan adalah roti goreng beku (frozen sandwich). Royal Sandwich merupakan piooner produk roti goreng beku (frozen sandwich) yang memasarkan produknya melalui media sosial dengan varian dan rasa yang berbeda sejak awal tahun 2011. Kemudian Royal Sandwich juga harus mampu menyakinkan konsumen terhadap produk yang dijualnya melalui media sosial.

Seiring dengan perkembangan zaman dan semakin meningkatnya permintaan dari konsumen akan kepraktisan, maka dikembangkanlah suatu roti dengan inovasi dan varian yang berbeda dari biasanya yaitu sandwich (roti lapis) yang berisi daging, sosis, selai, mayonase yang digoreng terlebih dahulu sebelum disajikan.

Hadirnya teknologi internet mengubah pola dan cara berpromosi bagi perusahaan dan juga UKM (Usaha Kecil Menengah). Royal Sandwich merupakan salah satu usaha yang memanfaatkan teknologi internet seperti facebook, twitter dan website sebagai media promosi produknya.

Produk ini membuat akun @Royal_Sandwich di twitter sebagai alat atau media untuk menyajikan informasi dan melakukan komunikasi dan promosi kepada konsumennya atau pengikutnya (followers). Melalui akun media sosial yang dimilikinya di facebook, twitter dan website, Royal Sandwich melakukan penjualan produk sampai melakukan promosi dengan memberikan informasi semenarik mungkin hingga konsumen menjadi tertarik untuk membeli produknya. Kegiatan promosi ini merupakan suatu bentuk promosi yang menjadi fokus utama bagi Royal Sandwich 
dalam mempromosikan produknya saat ini. Tingkat efektivitas promosi di media sosial perlu dibandingkan dengan bentuk promosilain yang sesuai dengan tingkat pasar dan anggaran (budget) dari perusahaan tersebut. Selama ini juga belum ada perusahaan sejenis yang memasarkan produk sandwich goreng melalui media sosial.

Berdasarkan penjelasan diatas, dengan demikian diperlukan adanya penelitian mengenai Efektivitas Media Promosi Pada Produk Sandwich Goreng Merek Royal Sandwich. Penelitian ini bertujuan untuk mengetahui efektivitas promosi yang diterapkan oleh Royal Sandwich.

\section{METODOLOGI PENELITIAN}

\section{Lokasi dan Waktu Penelitian}

Penelitian ini dilakukan di rumah produksi Royal Sandwich yang beralamat di J1. Merak 3/55 komplek Inkopol BekasiBarat. Pemilihan tempat ini dilakukan secara sengaja (purposive) dengan pertimbangan bahwa Royal Sandwich merupakan usaha yang bergerak dibidang kuliner, namun aktivitas promosi pemasarannya dilakukan melalui media online dan untuk pengiriman barang melalui jasa pengiriman barang. Selain itu juga Royal Sandwich ini merupakan satu-satunya usaha sandwich goreng yang dipromosikan melalui media sosial. Penelitian ini akan dilakukan pada bulan Mei 2013 sampai Oktober 2013.

\section{Jenis dan Sumber Data}

Data yang digunakan dalam penelitian ini adalah data primer dan data sekunder yang bersifat kualitatif dan kuantitatif. Data primer berdasarkan wawancara dengan owner dan pengisian kuisioner oleh responden. Data sekunder bersumber dari data penjualan Royal Sandwich yang meliputi data penjualan selama 1 tahun terakhir ini dari 2012-2013 dan biaya promosi. Selain itu juga data diperoleh melalui buku, internet, skripsi, jurnal, tesis dan literatur-literatur yang relevan dengan penelitian ini.

\section{Metode Pengumpulan Data}

1. Kueisoner

Kuisioner merupakan suatu teknik pengumpulan data dengan memberikan atau menyebarkan daftar pertanyaan kepada responden dengan harapan memberikan respons atas daftar pertanyaan tersebut. Daftar pertanyaan dapat bersifat terbuka, yaitu jika jawabannya tidak ditentukan sebelumnya oleh peneliti dan dapat bersifat tertutup, yaitu alternatif jawaban telah ditentukan sebelunya oleh peneliti (Noor, 2011). Penggunaan kuisioner ini dilakukan dengan skala likert dan kuisioner ini akan diberikan kepada konsumen Royal Sandwich yang daftar pertanyaannya berkaitan dengan dengan tujuan penelitian.

2. Wawancara

Wawancara merupakan salah satu teknik pengambilan data yang dilakukan dengan berhadapan langsung dengan yang diwawancarai tetapi dapat juga diberikan daftar pertanyaan dahulu untuk dijawab pada kesempatan lain (Noor, 2011). Wawancara ini dilakukan dengan owner Royal Sandwich.

\section{Metode Penentuan Sampel}

Penarikan sampel dilakukan dengan teknik pengambilan Purposive Sampling yaitu teknik penentuan sampel dengan pertimbangan tertentu (Sugiono, 2009). Kriteria yang digunakan adalah responden pernah membeli produk Royal Sandwich 
minimal satu kali, dan juga responden telah mengetahui promosi yang dilakukan oleh Royal Sandwich di Facebook dan Twitter. Jumlah sampel yangdiambil sebanyak 125 responden. Dengan menggunakan teknik pengambilan sampel dari Rumus Slovin sebagai berikut:

$$
\begin{aligned}
& n=\frac{N}{N \cdot d^{2}+1}=\frac{306}{306(0,07)^{2}+1} \\
& =\frac{306}{2,4994} \\
& =122 \\
& \text { Keterangan: } \mathrm{n}=\mathrm{ukuran} \text { sampel } \\
& \mathrm{N}=\text { pupolasi } \\
& \mathrm{d}=\text { tingkat kesalahan }
\end{aligned}
$$

Populasi didapat dari data Pre Order (PO) pada bulan September 2013 dengan kriteria konsumen tersebut tidak melakukan pembelian berulang, jika melakukan pembelian berulang pada bulan yang sama maka akan diambil satu nama saja untuk dijadikan populasi.

\section{Metode Analisis dan Teknik Pengolahan Data}

Metode analisis data yang digunakan dalam penelitian ini adalah analisis kualitatif dan kuantitatif. Analisis kualitatif disajikan secara deskriptif mengenai gambaran umum perusahaan, lokasi perusahaan, proses

\begin{tabular}{|c|c|}
\hline Tujuan penelitian & Alat analisis \\
\hline $\begin{array}{l}\text { 1. Mengetahui macam-macam promosi } \\
\text { yang dilakukan oleh Royal Sandwich }\end{array}$ & Deskriptif tabulasi \\
\hline $\begin{array}{l}\text { 2. Menganalisis efektivitas media promosi } \\
\text { pada produk somolwich goreng merek } \\
\text { Royal Sandwich berdasarkan EPIC } \\
\text { Model. }\end{array}$ & EPIC Model \\
\hline $\begin{array}{l}\text { 3. Menganalisis efektivitas media promosi } \\
\text { pada produk scmawich goreng merek } \\
\text { Royal Sandwich berdasarkan dampak } \\
\text { peryualan. }\end{array}$ & Regresi linier sederhana \\
\hline
\end{tabular}
produksi dan produk yang dihasilkan, kegiatan promosi yang dilakukan oleh Royal Sandwich. Analisis kuantitatif digunakan untuk mengetahui pengaruh promosi terhadap tingkat penjualan.

\section{Uji Validitas}

Menurut Noor (2011) hal-hal pokok dalam uji validitas sebagai berikut:

1. Uji ini sebenarnya untuk melihat kelayakan butir-butir pertanyaan dalam kuisioner tersebut dapat mendefinisikan suatu variabel.

2. Daftar pertanyaan ini pada umumnya untuk mendukung suatu kelompok variabel tertentu.

3. Uji validitas dilakukan disetiap butir pertanyaan. Hasilnya dibandingkan dengan $r$ tabel $\mid \mathrm{df}=\mathrm{n}-\mathrm{k}$ dengan tingkat kesalahan $7 \%$.

4. Jika $r$ hitung $\leq \mathrm{r}$ tabel, maka item variabel itu valid.

\section{Uji Reliabilitas}

Pengukuran keandalan dilakukan dengan menggunakan Alpha Cronbach adalah koefisien keandalan yang menunjukan seberapa baiknya item/butir dalamsuatu kumpulan secara posotif berkorelasi satu sama lain. Hal-hal pokok dalam uji reliabilitas ini sebagai berikut:

1. Untuk menilai kestabilan dan konsistensi respomden dalam menjawab kuisioner. Kuisioner tersebut mencerminkan konstruk sebagai dimensi suatu variabel yang disusun dalam bentuk pertanyaan. 
2. Uji reliabilitas dilakukan secara bersamasama terhadap seluruh pertanyaan.

3. Penilaian koefisien Alpha Cronbach berdasarkan aturan sebagai berikut:

$0,00-0,20=$ Kurang Reliabel

$>0,20-0,40=$ Agak Reliabel

$>0,40-0,60=$ Cukup Reliabel

$>0,60-0,80=$ Reliabel

$>0,80-1,00=$ Sangat Reliabel

Untuk melakukan uji validitas dan reliabilitas memerlukan jumlah responden minimal 30 orang (Noor, 2011:130).

\section{Analisis Deskriptif}

Analisis deskriptif tabulasi dilakukan untuk mengetahui gambaran umum mengenai karakteristik konsumen Royal Sandwich dan juga untuk mengetahui kegiatan promosi apa saja yang dilakukan Royal Sandwich. Data yang digunakan dalam analisis deskriptif adalah baik data primer maupun sekunder yang berupa data kualitatif dan data kualitatif.

\section{EPIC Model}

Efektivitas media promosi yang berkaitan dengan pengingatan dan persuasi dapat diukur melalui EPIC Model yang dikembangkan oleh AC. Nielsen, salah satu perusahaan terkemuka di dunia (Rangkuti, 2009:339) mencakup empat dimesi kritis yaitu: empati, persuasi, dampak dan komunikasi (Emphaty, Persuation, Impact and Communication).

\section{Dimensi Empati (Emphaty)}

Dimensi empati menginformasikan apakah konsumen menyukai promosi dan menggambarkan bagaimana konsumen melihat hubungan antara promosi dengan pribadi mereka. Dimensi empati memberikan informasi yang berharga tentang daya tarik suatu produk.

\section{Dimensi Persuasi (Persuation)}

Dimesi persuasi menginformasikan apa yang dapat diberikan suatu promosi untuk penguatan karakter produk, sehingga pemasar memperoleh pemahaman tentang dampak promosi terhadap keinginan konsumen untuk mengembangkan daya tarik produk.

\section{Dimensi Dampak (Impact)}

Dimensi dampak (impact) menunjukan pakah suatu promosi mampu melibatkan konsumen dalam pesan yang disampaikan. Dampak yang diinginkan dari hasik promosi adalah jumlah pengetahuan produk (product knowledge) yang dicapai konsumen melalui tingkat keterlibatan konsumen dengan produk, dan untuk mengetahui dampak kegiatan promosi terhadap melalukan pembelian produk.

\section{Dimensi Komunikasi (Communication)}

Dimensi komunikasi memberikan informasi tentang kemampuan konsumen dalam mengingat pesan untam yang disampaikan, pemahaman konsumen, serta kekuatan kesan yang ditinggalkan pesan tersebut.

Kemudian dari empat dimensi tersebut, data dianalisis dengan menggunakan skor ratarata berbobot yaitu setiap jawaban responden diberikan bobot. Cara menghitung skor adalah menjumlahkan seluruh hasil kali nilai masing-masing bobotnya dengan jumlah total frekuensi (Durianto dalam Andri, 2012:41). 


$$
\begin{array}{|l|l}
X=\frac{\sum f i \cdot w i}{\sum f i} & \begin{array}{l}
\text { Keterangan } \\
\text { X= Rataan Berbobot } \\
f=\text { Frekuensi } \\
w i=\text { Bobot }
\end{array}
\end{array}
$$

Langkah selanjutnya adalah menggunakan rentang skala. Penilaian untuk menentukan posisi tanggapan responden dengan menggunakan nilai skor setiap variabel. Bobot alternatif jawaban yang terbentuk dari teknik skala peringkat dengan menggunakan skala antara 1 hingga 5 yang menggambarkan posisi sangat negatif ke posisi yang sangat positif. Rentang skala dihitung dengan rumus sebagai berikut (Durianto dalam Andri, 2012:42).

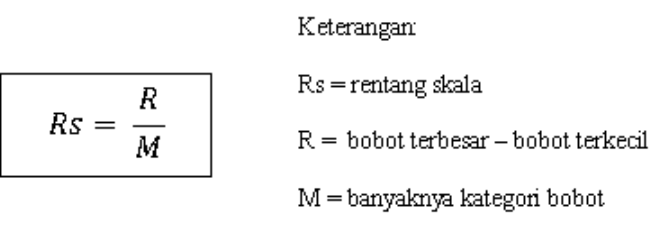

Skala yang digunakan adalah skala likert, yaitu skala 1 hingga 5, maka rentang skala penilaiannya adalah sebesar 0,8 . Hal ini didapatkan dari hasil rumus berikut:

$$
\boldsymbol{R} \boldsymbol{s}=\frac{\mathbf{5 - 1}}{\mathbf{5}}=0,8
$$

Rentang skala (Rs) tersebut kemudian digunakan ke dalam rentang skala keputusan sebagai bahan pengambilan keputusan dari hasil analisis EPIC Model. Hal ini dapat dilihat pada Tabel 2 .

Tabel 2. Skala Penilaian EPIC Model
\begin{tabular}{|c|l|l|}
\hline \multirow{2}{*}{ No } & \multicolumn{2}{|c|}{ Skala penilaian EPIC Model } \\
\cline { 2 - 3 } & Rentang skala & Penilaian \\
\hline 1. & $1,00-1,80$ & Sangat tidak efektif \\
\hline 2. & $1,81-2,60$ & Tidak efektif \\
\hline 3. & $2,61-3,40$ & Cukup efektif \\
\hline 4. & $3,41-4,20$ & Efektif \\
\hline 5. & $4,21-5,00$ & Sangat efektif \\
\hline
\end{tabular}

Langkah terakhir adalah menentukan nilai EPIC Rate dengan rumus sebagai berikut.
EPIC Rate $=\frac{X E m p a t i-X P \text { ersuasi }-X D a m p a k-X \text { Komunikasi }}{N}$

\section{Analisis Regresi Linier Sederhana}

Analisis regresi adalah suatu proses melakukan estimasi untuk memperoleh suatu hubungan fungsional antara variabel acak Y dengan variabel X. Efektivitas media promosi dari dampak penjualan dapat diketahui dengan cara menganalisis pengaruh biaya promosi terhadap volume penjualan produk RoyalSandwich. Metode analisis yang digunakan adalah regresi linier sederhana, dengan persamaan sebagai berikut:

$$
\mathrm{Y}=\mathbf{a}+\boldsymbol{\beta} \mathbf{x}+\mathbf{e}
$$

Dimana:

$\mathrm{Y}=$ volume penjualan Royal Sandwich

$\mathrm{a}=$ konstanta

$\beta=$ koefisien arah regresi variabel bebas

$\mathrm{x}=$ biaya promosi

\section{Uji F}

Uji ini digunakan untuk mengetahui apakah variabel bebas $(\mathrm{X} 1, \mathrm{X} 2, \ldots . \mathrm{Xn})$ secara bersama-sama berpengaruh secara signifikan terhadap variabel terikat (Y).

Hipotesis Penelitian:

$\mathrm{HO}$ : bi $=0$, artinya biaya promosi secara bersama-sama tidak berpengaruh secara signifikan terhadap volume penjualan.

$\mathrm{H} 1$ : bi $=0$, artinya biaya promosi secara bersama-sama berpengaruh secara signifikan terhadap volume penjualan.

Kriteria pengujian :

HO : ditolak, jika Fhitung > Ftabel, derajat bebas $(\mathrm{df}=\mathrm{n}-\mathrm{k}-1)$ atau $\mathrm{sig}<\mathrm{a}$

H1 : diterima, jika Fhitung < Ftabel, derajat bebas $(\mathrm{df}=\mathrm{n}-\mathrm{k}-1)$ atau $\mathrm{sig}<\mathrm{a}$

\section{HASIL DAN PEMBAHASAN}




\section{Media Promosi yang Digunakan Royal Sandwich}

Kegiatan promosi yang dilakukan Royal Sandwich berupa periklan. Kegiatan periklanan dilakukan dengan menggunakan media sosial sebagai media promosinya. Promosi tersebut menampilkan keunikan Royal Sandwich sebagai produk frozen sandwich (sandwich beku) dengan berbagai varian rasa yang berbeda. Hal ini sangat penting untuk menarik minat konsumen agar membeli produk Royal Sandwich. Kegiatan promosi yang dilakukan oleh Royal Sandwich lebih menekankan pada promosi melalui pengiklanan di media sosial.

Periklanan merupakan bentuk promosi yang utama digunakan oleh Royal Sandwich. Tujuan Royal Sandwich melakukan kegiatan promosi ini adalah untuk menstimulasi terjadinya kesadaran (awareness), ketertarikan (interest), dan berakhir pada tindakan pembelian (purchase) yang dilakukan oleh target konsumen terhadap produk yang ditawarkan perusahaan. Oleh karena itu perusahaan memperhatikan median dan isi pesan yang ingin disampaikan kepada target konsumen agar kegiatan promosi tersebut berjalan efektif.

\section{Analisis Efektivitas Promosi Royal Sandwich berdasarkan EPIC Model}

Analisis mengenai efektivitas promosi di social media penting untuk dilakukan karena saat ini sedang marak sekali konsumen yang menggunkan social media. Dengan biaya yang murah produsen dapat melakukan promosi word of mouth melalui social media sehingga perlu diketahui apakah informasi di social media yang ingin disampaikan dapat diterima dengan baik oleh konsumen. Hal iniperlu dilakukan sebagai bahan pertimbangan bagi produsen dalam merumuskan strategi komunikasi pemasaran selanjutnya.
Menilai keefektifan promosi dapat dilakukan dengan mengukur dua dampak yaitu dampak penjualan dan dampak komunikasi. Dampak penjualan diukur dengan menggunakan analisis dengan membandingkan antara biaya promosi dengan volume penjualan. Sedangkan untuk mengukur dampak komunikasi dilakukan dengan menggunakan EPIC Model. Pengukuran keefektifan kegiatan promosi Royal Sandwich dilakukan dengan menganalisis pertanyaan dan jawaban dari responden yang telah mengisi kuesioner.

EPIC Model terdiri atas empat dimensi yaitu dimensi empathy, dimensi persuation, dimensi impact dan dimensi communication. Dimensi-dimensi tersebut terwakili oleh beberapa pertanyaan yang diajukan kepada responden didalam kuesioner. Pertanyaan tersebut mencerminkan dimensi-dimensi dalam EPIC Model. Setelah diketahui jawaban dari masing-masing responden kemudian dilakukan perhitungan dengan analisis EPIC Model.

\section{EPIC Model untuk Facebook}

Berdasarkan EPIC Model, maka diketahui hasil analisis tingkat efektivitas promosi produk Royal Sandwich melalui Facebook dari masing-masing dimensi, yaitu:

\section{Empathy (Empati)}

Dimensi empati di dalam kuesioner disajikan oleh dua butir pertanyaan, yaitu pertanyaan (1b) dan pertanyaan (2b). Hasil jawaban kuesioner tersebut dimasukan dalam analisis perhitungan skor rata-rata berbobot yang terdapat di Tabel 12 . 


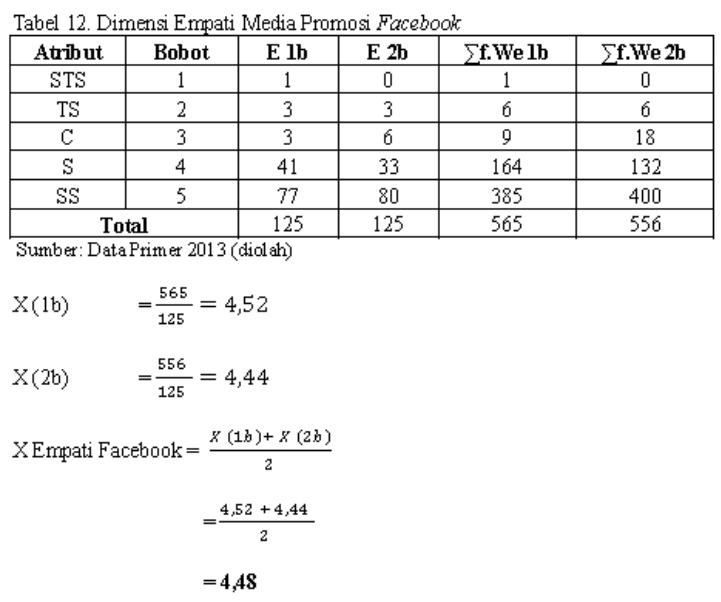

Berdasarkan hasil tingkat efektivitas promosi pada produk Royal Sandwich melalui Facebook, maka diketahui nilai $\mathrm{X}$ Empati sebesar 4,48. Nilai ini masuk dalam rentang skala sangat efektif $(4,21-5,00)$. Hal ini menginformasikan bahwa target konsumen menyukai promosi yang dilakukan melalui facebook karena dapat memberikan informasi yang berharga tentang daya tarik produk Royal Sandwich.

Daya tarik produk Royal Sandwich yang dipromosikan melalui Facebook antara lain: (1) Gambar yang ditampilkan di Facebook sangat menarik dan dapat menggugah selera konsumen untuk mencoba produk Royal Sandwich ini. Selain itu dari gambar yang ditampilkan membuat konsumen menjadi penasaran dengan rasa Royal Sandwich itu sendiri. (2) Produk Royal Sandwich sudah terjamin akan kehalalan dan keamanan untuk dikonsumsi dengan diperolehnya sertifikat Halaldari MUI. (3) Tampilan produk Royal Sandwich yang berbentuk segitiga dan persegi panjang juga merupakan salah satu daya tarik tersendiri yang membuat konsumen menyukai promosi ini. Royal Sandwich membuat tampilan produk sandwich yang berbeda dari biasanya, yaitu dengan membuat tampilan yang lebih kecil sehingga memudahkan konsumen dalam mengkonsumsi produk tersebut.

\section{Persuasion (Persuasif)}

Dimensi persuasif dalam kuesioner disajikan dalam dua butir pertanyaan, yaitu pertanyaan (3b) dan pertanyaan (4b). Hasil jawaban kuesioner tersebut dimasukkan dalam analisis perhitungan skor rata-rata berbobot yang terdapat di Tabel 13 .

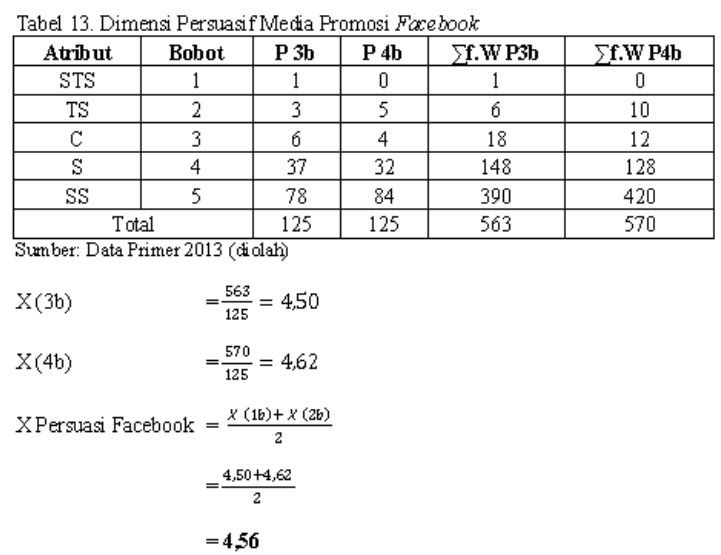

Berdasarkan tingkat efektivitas media promosi pada produk Royal Sandwich melalui Facebook maka diketahui nilai $\mathrm{X}$ Persuasif sebesar 4,56. Nilai ini masuk dalam rentang skala sangat efektif $(4,21$ 5,00). Hal inimenginformasikan bahwa target konsumen tertarik untuk mengetahui lebih banyak informasi mengenai produk Royal Sandwich. Seperti yang dijelaskan oleh (Lee \& Jonshon, 2007:110) pengiklan dapat mempengaruhi para pembeli dengan membantu mereka mengenali kebutuhan yang dapat dipenuhi oleh produk sang pengiklan. Informasi yang diberikan melalui Facebook mampu meningkatkan dan menguatkan karakter dari produk Royal Sandwich sehingga mendorong konsumen untuk membeli produk tersebut. Hal-hal yang menjadi alasan konsumen untuk membeli Royal Sandwich antara lain sebagai berikut:

a. Rasa penasaran konsumen dengan gambar produk Royal Sandwich di Facebook membuat mereka akhirnya membeli dan setelah membeli konsumen merasa puas 
karena produk Royal Sandwich yang konsumen beli sesuai dengan gambar yang ada di Facebook.

b. Produk Rayal Sandwich praktis. Untuk mengkonsumsinya konsumen hanya perlu menggorengnya saja.

c. Royal Sandwich sudah memiliki sertifikat kehalalan dari MUI.

d. Kemasan Royal Sandwich yang kedap udara membuat produk menjadi lebih higienis.

e. Pelayanan yang diberikan sangat cepat dan juga ramah.

\section{Impact (Dampak)}

Dimensi Impact (dampak) menunjukan apakah suatu merek dapat terlihat lebih menonjol dibandingkan dengan merek lainnya pada kategori serupa, serta memberikan informasi seberapa besar keterlibatan konsumen dalam pesan yang disampaikan. Dimensi Impact (dampak) dalam kuesioner disajikan dalam satubuah pertanyaan, yaitu pertanyaan (5b). Hasil jawaban kuesioner tersebut dimasukan dalam analisis perhitungan rata-rata berbobot pada Tabel 14, yaitu:

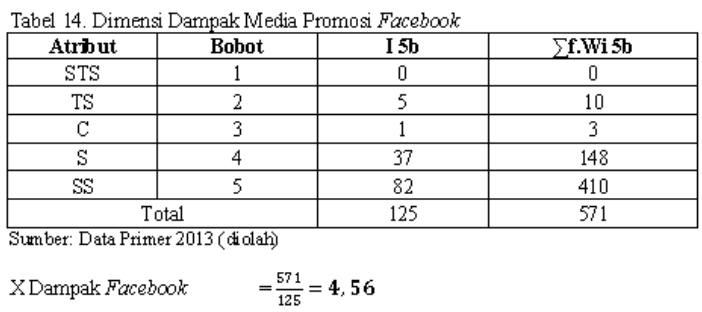

Berdasarkan hasil analisis tingkat efektivitas media promosi pada produk Royal Sandwich melalui Facebook, maka diketahui nilai X Dampak sebesar 4,56. Nilai ini masuk dalam rentang skala sangat efektif $(4,20-5,00)$. Hal ini menginformasikan bahwa promosi melalui
Facebook sangat efektif membuat target konsumen lebih bertambah pengetahuannya tentang produk Royal Sandwich. Dengan bertambahnya pengetahuan berarti konsumen sudah mulai kenal dengan produk, kemudian akan tumbuh minat untuk membeli dan akhirnya konsumen membeli produk (Simamora. 2003:288)

Beberapa pengetahuan produk tersebut antara lain: (1) Royal Sandwich merupakan frozen sandwich yang memiliki delapan varian rasa. (2) Produk ini sudah memiliki sertifikat halal dari MUI, dan sertifikat produksi pangan industri rumah tangga ( $\mathrm{P}$ IRT) dari Dinas kesehatan kota Bekasi. (3) Tanpa bahan pengawet dan MSG.

\section{Communication (Komunikasi)}

Dimensi komunikasi menunjukan tentang kemampuan konsumen dalam mengingat pesan utama yang disajikan oleh pesan tersebut. Penelitian inimengukur kejelasan dari pesan yang ingin disampaikan dan kemampuan promosi untuk berkomunikasi dengan konsumen. Dimensi komunikasi dalam kuesioner disajikan dalam dua buah pertanyaan, yaitu pertanyaan (6b) dan (7b). Hasil jawaban kuesioner tersebut dimasukan dalam analisis perhitungan rata-rata berbobot pada Tabel 15, yaitu:

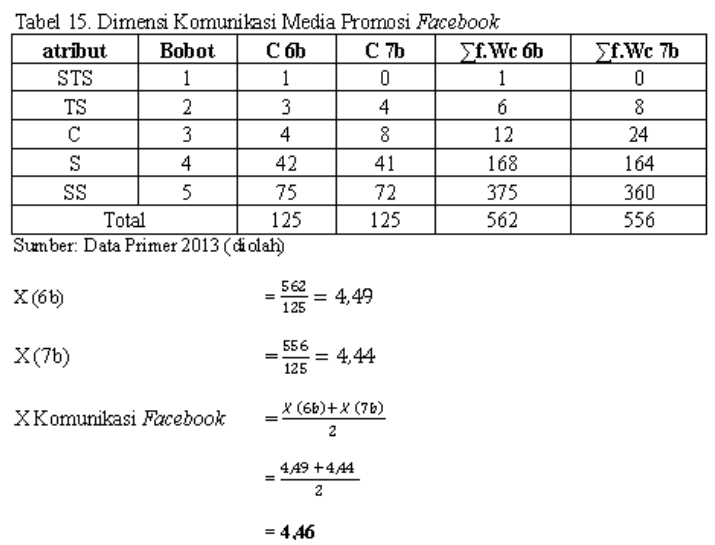

Berdasarkan hasil analisis tingkat efektivitas media promosi pada produk Royal Sandwich melalui Facebook, maka 
diketahui nilai $\mathrm{X}$ komunikasi sebesar 4,46. Nilai ini masuk dalam rentang skala sangat efektif $(4,20-5,00)$. Sehingga dapat disimpulkan bahwa promosi yang dilakukan Royal Sandwich melalui Facebook mempunyai respon yang sangat efektif terhadap konsumen.

Responden menyatakan setuju karena pesan yang disampaikan di Facebook dapat dimengerti. Pesan dalam promosi tersebut adalah pemberitahuan setiap kali Royal Sandwich mengeluarkan rasa baru. Responden dapat mengingatpesan utama yang disampaikan dan telah meninggalkan kesan yang kuat dengan pemahaman produk yang tinggi. Promosi setiap kali ada varian rasa baru disertai dengan foto yang sangat menarik dengan komposisi warna yang indah.

\section{EPIC Rate Facebook}

Hasil perhitungan empat dimensi di atas, yaitu dimensi empati, persuasi, dampak, dan komunikasi berada dalam rentang skala sangat efektif. Keempat nilai dimensi tersebut dijumlahkan untuk mendapatkan nila rata-rata untuk EPIC Rate.

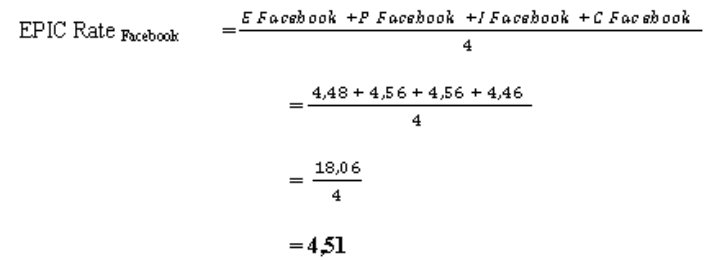

Nilai EPIC Rate yang didapat secara keseluruhan adalah 4,51. Nilai ini berada dalam rentang skala $(4,21-5,00)$ yang berarti secara keseluruhan promosi yang telah dilakukan Royal Sandwich sangat efektif. Artinya promosi yang dilakukan sudah sesuai dengan tujuan yang ingin dicapai. Promosi tersebut telah menarik perhatian dan dapat menambah pengetahuan serta pesan yang disampaikan dapat dimengerti responden sehingga mendorong mereka untuk melakukan pembelian produk Royal Sandwich.

\section{EPIC Model untuk Twitter}

Berdasarkan EPIC Model, maka diketahui hasil analisis tingkat efektivitas promosi produk Royal Sandwich melalui Twitter dari masing-masing dimensi, yaitu:

\section{Empathy (Empati)}

Dimensi empati di dalam kuesioner disajikan oleh dua butir pertanyaan, yaitu pertanyaan (1a) dan pertanyaan (2a). hasil jawaban kuesioner tersebut dimasukan dalam analisis perhitungan skor rata-rata berbobot yang terdapat di Tabel 16 .

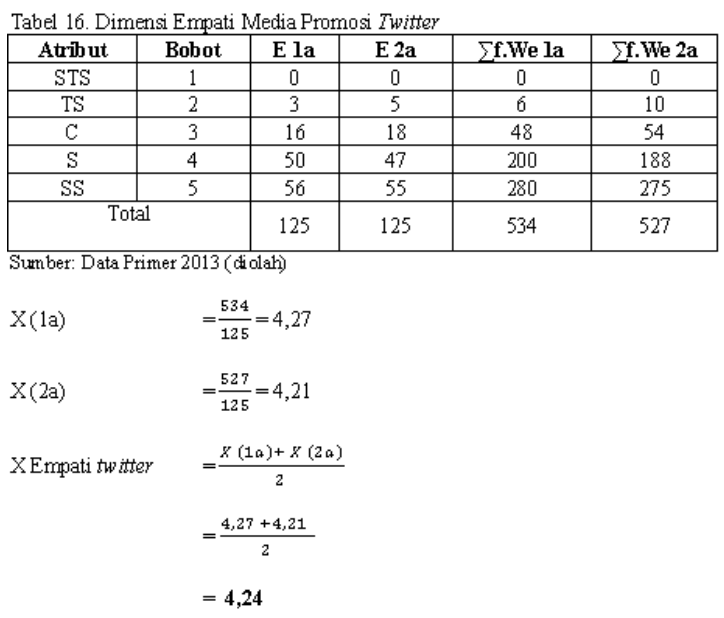

Berdasarkan hasil analisis tingkat efektivitas promosi produk Royal Sandwich melalui Twitter, dapat diketahui nilai $\mathrm{X}$ Empati Twitter sebesar 4,24. Nilai ini masuk dalam rentang skala sangat efektif $(4,21$ $5,00)$. Hal ini menjelaskan bahwa konsumen sangat menyukai promosi yang dilakukan Royal Sandwich melalui Twitter karena dapat memberikan informasi yang berharga tentang daya tarik produk Royal Sandwich.

Daya tarik produk Royal Sandwich yang dipromosikan melalui Twitter antara lain: (1) Gambar yang ditampilkan di Twitter sangat menarik dan menggugah selera konsumen untuk mencoba produk Royal Sandwich ini. Selain itu dari gambar 
yang ditampilkan membuat konsumen menjadi penasaran dengan rasa Royal Sandwich itu sendiri. (2) Tampilan produk Royal Sandwich yang berbentuk segitiga dan persegi panjang juga merupakan salah satu daya tarik tersendiri yang membuat konsumen menyukai promosi ini. Royal Sandwich membuat tampilan produk sandwich yang berbeda dari biasanya, yaitu dengan membuat tampilan yang lebih kecil sehingga memudahkan konsumen dalam mengkonsumsi produk tersebut.

\section{Persuation (Persuasi)}

Dimensi persuasi dalam kuesioner disajikan dalam dua butir pertanyaan, yaitu pertanyaan (3a) dan pertanyaan (4a). Hasil jawaban kuesioner tersebut dimasukkan dalam analisis perhitungan skor rata-rata berbobot yang terdapat di Tabel 17 .

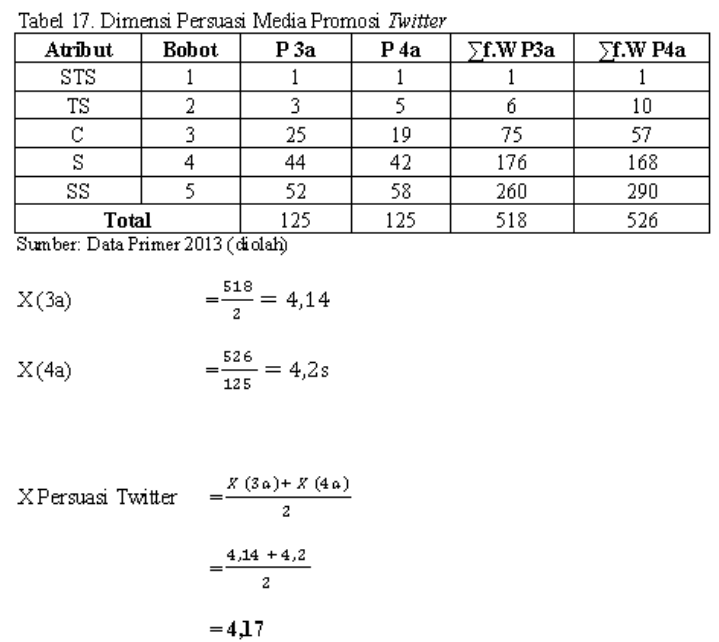

Berdasarkan hasil analisis tingkat efektivitas promosi produk Royal Sandwich melalui Twitter pada tabel 8, dapat diketahui nilai X Persuasi Twitter sebesar 4,17. Nilai ini masuk dalam rentang skala efektif $(3,41$ - 4,20). Dapat disimpulkan bahwa promosi yang telah dilakukan Royal Sandwich mempunyai respon yang efektif terhadap konsumen. Konsumen setuju jija promosi yang telah dilakukan Royal Sandwich membuat mereka menjadi tertarik terhadap promosinya dan berkeinginan untuk membeli. Hal ini disebabkan Royal Sandwich telah mampu menguatkan daya tarik produk yang ditawarkan sehingga konsumen menjadi yakin untuk membeli produk Royal Sandwich. Daya tarinya adalah gambar yang ditampilkan di Twitter, kemasan produk Royal Sandwich dan varian rasa produk Royal Sandwich yang sesuai dengan selera konsumen dapat membuat konsumen untuk melakukan pembelian berulang.

\section{Impact (Dampak)}

Dimensi dampak menunjukkan apakah suatu merek dapat terlihat lebih menonjol dibanding merek lainnya pada kategori serupa, serta memberikan informasi seberapa besar keterlibatan konsumen dalam pesan yang disampaikan. Keterlibatan ini mengacu pada persepsi konsumen tentang pentingnya suatu objek, kejadian, atau aktivitas, dimana keterlibatan akan mengarahkan perilaku konsumen untuk membuat keputusan. Dampak (impact) yang diinginkan darihasil promosi adalah jumlah pengetahuan terhadap produk yang diperoleh konsumen melalui tingkat keterlibatan dengan produk dan atau proses pemilihan.

Dimensi dampak dalam kuesioner disajikan dalam satu butir pertanyaan yaitu pertanyaan (5a). Hasil jawaban kuesioner tersebut dimasukkan dalam analisis perhitungan skor rata-rata berbobot yang terdapat di Tabel 18 .

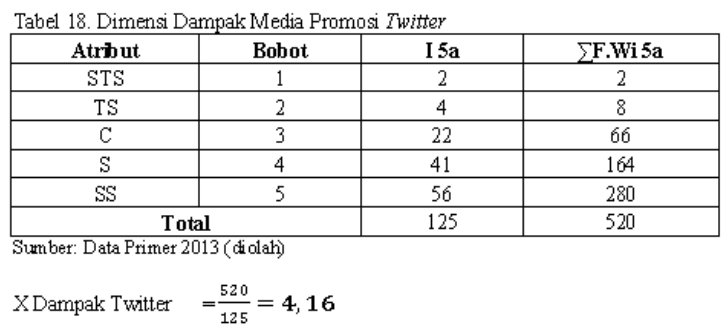

Berdasarkan hasil analisis tingkat efektivitas promosi produk Royal Sandwich melalui Twitter pada tabel 9, dapat diketahui nilai X Dampak Twitter sebesar 4,16. Nilai 
ini masuk dalam rentang skala efektif $(3,41$ - 4,20). Dapat disimpulkan bahwa promosi yang telah dilakukan Royal Sandwich mempunyai respon yang efektif. Responden mengatakan setuju bahwa promosi yang dilakukan Royal Sandwich di Twitter dapat membuat responden tahu tentang produk Royal Sandwich. Salah satu penyebabnya adalah dalam berpromosi melalui Twitter, Royal Sandwich memposting tweet dan gambar tentang produk Royal Sandwich baik mengenai rasa, kemasan, label kehalalan produk sampai dengan menyajikan cara menggoreng frozen sandwich walaupun dengan menggunakan kalimat yang singkat, karena untuk promosi melalui Twitter hanya terbatas 160 karakter huruf saja.

\section{Communication (Komunikasi)}

Dimensi komunikasi menunjukkan tentang kemampuan konsumen dalam mengingat pesan utama yang disampaikan, pemahaman konsumen, serta kekuatan kesan yang ditinggalkan oleh pesan tersebut. Penelitian ini mengukur kejelasan dari pesan yang ingin disampaikan, kemampuan promosi untuk berkomunikasi dengan konsumen, dan kesesuaian pemakaian slogan dalam promosi yang dilakukan oleh Royal Sandwich. Dimensi komunikasi dalam kuesioner disajikan dalam satu butir pertanyaan yaitu pertanyaan (6a) dan pertanyaan (7a). Hasil jawaban kuesioner tersebut dimasukkan dalam analisis perhitungan skor rata-rata berbobot yang terdapat di Tabel 19.

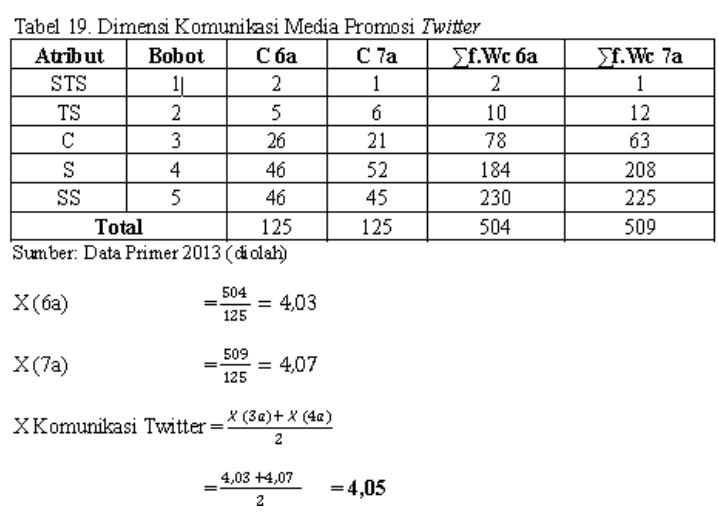

Berdasarkan hasil analisis tingkat efektivitas promosi produk Royal Sandwich melalui Twitter pada tabel 10, dapat diketahui nilai X komunikasi Twitter sebesar 4,05. Nilai ini masuk dalam rentang skala efektif $(3,41$ - 4,20).Dapat disimpulkan bahwa promosi yang dilakukan oleh Royal Sandwich mempunyai respon yang efektif terhadap responden.

Responden menyatakan setuju karena informasi tentang produk Royal Sandwich yang disampaikan melalui Twitter sangat jelas sehingga konsumen tidak perlu bertanya kembali mengenai produk Royal Sandwich. Hal ini disebabkan semua informasi mengenai produk sudah diposting di Twitter@Royal_Sandwich.

\section{EPIC Rate Twitter}

Secara keseluruhan EPIC Rate Twitter adalah sebagai berikut:

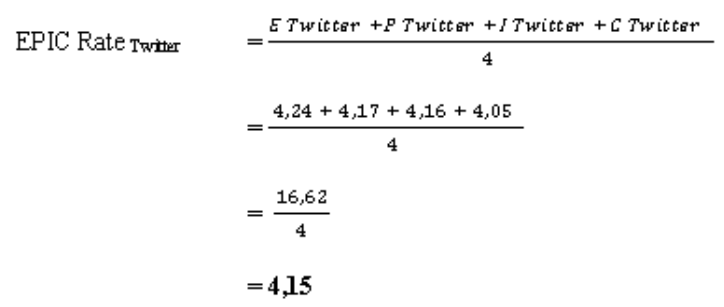

Berdasarkan hasil perhitungan EPIC Rate Twitter, maka diperoleh nilai sebesar 4,15. Nilai ini masuk dalam rentang skala efektif $(3,14-4,20)$. Dengan demikian, dapat disimpulkan bahwa efektivitas promosi produk Royal Sandwich melalui 
Twitter berdasarkan EPIC Model mencapai tingkat efektif. Artinya promosi yang dilakukan sudah sesuai dengan tujuan promosi yang ingin dicapai. Promosi tersebut disukai, menarik perhatian, dapat menambah pengetahuan serta pesan yang disampaikan dapat mengerti responden sehingga terdorong untuk melakukan pembelian produk Royal Sandwich.

\section{Perbandingan Tingkat Efektivitas Media Promosi}

Berdasarkan hasil pengukuran tingkat efektivitas media promosi yang digunakan oleh Royal Sandwich dengan menggunakan EPIC Model, maka diperoleh perbandingan skor rata-rata dari masing-masing dimensi yaitu:

Tabel 20. Perbandingan skor rata-rata dari dua media promosi berdasarkan EPIC
\begin{tabular}{|c|l|c|c|}
\hline \multirow{2}{*}{ No. } & \multicolumn{2}{|c|}{ EPIC model } & \multicolumn{2}{|c|}{ Media promosi } \\
\cline { 3 - 4 } & & Facebook & Twitter \\
\hline 1. & Empati (Empathy) & $\mathbf{4 , 4 8}$ & 4,24 \\
\hline 2. & Persuasi (Pesuation) & $\mathbf{4 , 5 6}$ & 4,17 \\
\hline 3. & Dampak (mpact) & $\mathbf{4 , 5 6}$ & 4,16 \\
\hline 4. & Komunikasi (Communication) & $\mathbf{4 , 4 6}$ & 4,05 \\
\hline
\end{tabular}
Sumber: Data Primer 2013(diolah)

\section{Empati (Empathy)}

Berdasarkan perbandingan skor ratarata pada Tabel 20. maka dapat diketahui bahwa skor rata-rata dimensi empati yang tertinggi adalah Facebook sebesar 4,48. Hal ini menginformasikan bahwa Facebook dapat lebih spesifik menyampaikan tentang daya tarik produk Royal Sandwich. Facebook juga tidak mempunyai batasan teks seperti Twitter sehingga dapat menungkinkan admin untuk menjelaskan lebih rinci tentang produk Royal Sandwich agar konsumen lebih memahaminya dengan benar. Hal ini yang membuat nilai empati Facebook lebih tinggi dibandingkan Twitter.

\section{Persuasi (Persuation)}

Berdasarkan perbandingan skor ratarata pada Tabel 20 maka diketahui bahwa skor rata-rata dimensi persuasi yang tertinggi adalah Facebook sebesar 4,56. Hal ini menginformasikan bahwa konsumen tertarik untuk mengetahui lebih banyak informasi mengenai produk Royal Sandwich dengan promosi yang dilakukan oleh Royal Sandwich melalui Facebook sehingga membuatkonsumen berkeinginan untuk membeli produk Royal Sandwich. Hal ini disebabkan karena Facebook Royal Sandwich telah mampu menguatkan daya tarik produk yang ditawarkan sehingga konsumen menjadi yakin untuk membeli produk tersebut. daya tariknya dengan mengadakan kuis yang berhadian produk Royal Sandwich di setiap minggunya. Dengan adanya kuis ini membuat konsumen merasa perlu mengetahui lebih banyak informasi tentang Royal Sandwich.

\section{Dampak (Impact)}

Berdasarkan perbandingan skor ratarata pada Tabel 20 maka diketahui bahwa skor rata-rata dimensi dampak yang tertinggi adalah Facebook sebesar 4,56. Nilai ini berada dalam rentang skala 4,20 - 5,00 yang bernilai sangat efektif. Sehingga dapat disimpulkan bahwa promosi yang dilakukan oleh Royal Sandwich melalui Facebook mempunyai respon yang sangat efektif. Konsumen menyatakan setuju bahwa promosi yang telah dilakukan Royal Sandwich dapat menambah pengetahuan mereka tentang produk Royal Sandwich.

\section{Komunikasi (Communication)}

Berdasarkan perbandingan skor ratarata pada Tabel 20 maka diketahui bahwa skor rata-rata dimensi komunikasi yang tertinggi adalah Facebook sebesar 4,46. Nilai ini berada dalam rentang skala 4,20 5,00 yang bernilaisangat efektif. Sehingga dapat disimpulkan bahwa promosi yang dilakukan oleh Royal Sandwich melalui Facebook mempunyai respon yang sangat efektif. \ Dengan demikian penggunaan slogan "New Taste For Sandwich Lover" menjadi pilihan Royal Sandwich karena 
dapat menggambarkan secara utuh tertang produk itu sendiri.

\section{Efektivitas Promosi Royal Sandwich berdasarkan Dampak Penjualan}

Analisis uji regresi sederhana merupakan alat analisis yang bertujuan untuk mengetahui apakah ada pengaruh secara bersama-sama antara variabel bebas dan variabel terikat sehingga berdasarkan pengolahan hasil uji regresi sederhana, maka diperoleh hasil menggunakan SPSS 16 yang dapat dilihat pada.

Tabel 21. Uji coefficients pada variabel bebas penelitian
\begin{tabular}{|l|r|r|r|r|r|}
\hline \multirow{3}{*}{ Mode1 } & \multicolumn{1}{|c|}{$\begin{array}{c}\text { Unstandardized } \\
\text { Coefficients }\end{array}$} & $\begin{array}{c}\text { Standardized } \\
\text { Coefficients }\end{array}$ & \multirow{2}{*}{$\mathrm{t}$} & \multirow{2}{*}{ Sig. } \\
\cline { 2 - 4 } & \multicolumn{1}{|c|}{$\mathrm{B}$} & Std. Error & Beta & & \\
\hline Constant & $4.418 \mathrm{E} 6$ & $4.261 \mathrm{E} 6$ & & 1.037 & .312 \\
\hline Promosi & 11.490 & 2.075 & .778 & 5.537 & .000 \\
\hline
\end{tabular}
Sumber: Data Primer (diol ah) 2013

Persamaan yang didapat pada penelitian ini adalah:

$\mathrm{Y}=4.418 \mathrm{E} 6+11.490 \mathrm{X}+\mathrm{e}$

Pada persamaan tersebut menunjukan bahwa nilai konstanta yang dimiliki memberikan pengertian apabila promosi tidak memiliki nilai maka volume penjualan Royal Sandwich sebesar Rp. 4.418.666. Hal ini terjadi karena biaya promosi yang telah dikeluarkan Royal Sandwich ternyata dapat menarik perhatian konsumen untuk melakukan pembelian sehingga berdampak pada penjualannya.

Uji signifikansi simultan (Uji F) dalam penelitian ini digunakan untuk menunjukan apakah variabel bebas yang dimasukkan dalam model mempunyai pengaruh secara bersama-sama terhadap varibael terikat. Uji ini dapat dilakukan dengan membandingkan $\mathrm{F}$ hitung dengan $\mathrm{F}$ tabel. Pengolahan hasil data-data primer pada penelitian ini menggunakan SPSS 16. Pada Tabel 21 tersedia hasil pengolahan uji $\mathrm{F}$ pada analisis regresi sederhana yang telah dilakukan $\underset{\text { Tabel 22. Uji F (Uji simultan pengaruh variabel bebas terhadap variabel tidak }}{\text { dalam }}$

bebas)
\begin{tabular}{|l|c|c|c|c|c|}
\hline \multicolumn{1}{|c|}{ Model } & $\begin{array}{c}\text { Sum of } \\
\text { Squares }\end{array}$ & Df & $\begin{array}{c}\text { Mean } \\
\text { Square }\end{array}$ & F & Sig. \\
\hline Regression & $2.362 \mathrm{E} 15$ & 1 & $2.362 \mathrm{E} 15$ & 30.662 & $.000^{2}$ \\
\hline Residdal & $1.540 \mathrm{E} 15$ & 20 & $7.702 \mathrm{E} 13$ & & \\
\hline Total & $3.902 \mathrm{E} 15$ & 21 & & & \\
\hline
\end{tabular}
Sumber: Data Primer 2013 (didalah)

Berdasarkan hasil uji $\mathrm{F}$ dengan tingkat kepercayaan $93 \%$ yang terlihat pada Tabel 22 , diperoleh nilai df $1=20$ dan df $2=1$, maka di dapat nilai $F$ tabel yaitu 4.35 karena $\mathrm{F}$ hitung > F tabel, yaitu $30.6>4.35$ dan nilai probabilitas (sig) 0.000 artinya signifikansi lebih kecil dari alpha 0.10 $(0.000<0.10)$. Maka tolak H0 dan terima $\mathrm{H} 1$, yaitu variabel bebas yang diamati dengan tingkat kepercayaan $93 \%$ yaitu biaya promosi $(\mathrm{X})$ berpengaruh terhadap volume penjualan (Y) Royal Sandwich.

Pada Tabel 23, R yang didapatkan sebesar $77.8 \%$. Hasil yang didapatkan menunjukan bahwa pengaruh promosi terhadap volume penjualan dalam kisaran sedang.

\begin{tabular}{|c|c|c|c|}
\hline $\mathrm{R}$ & R Square & Adjusted R Square & $\begin{array}{l}\text { Std. error of the } \\
\text { estimate }\end{array}$ \\
\hline $.778^{\mathrm{a}}$ & .605 & .585 & 8776384.096 \\
\hline
\end{tabular}

Hasil pengolahan yang tampak pada Tabel 24, uji $R$ Square pada penelitian ini sebesar 0.605 . Artinya $60.5 \%$ dari nilai penjualan mampu dijelaskan oleh biaya promosi sedangkan sisanya $39.5 \%$ dijelaskan oleh faktor-faktor lain diluar penelitian ini. Hal ini menunjukan seberapa bagusnya model regresi yang dibentuk oleh variabel bebas dan variabel terikat.

\section{KESIMPULAN}

Berdasarkan hasil penelitian yang telah dibahas sebelumnya dapat ditarik kesimpulan sebagai berikut:

1. Kegiatan media promosi pada produk Royal Sandwich adalah berupa promosi melalui Facebook dan Twitter. Untuk di Facebook, Royal Sandwich menggunakan 
Fanpage sebagai sarana promosi. Sementara untuk di Twitter Royal Sandwich menggunakan jasa iklan dan juga endorse agar konsumen lebih tertarik untuk membeli.

2. Hasil analisis tingkat efektivitas media promosi pada produk sandwich goreng merek Royal Sandwich berdasarkan EPIC model menunjukan bahwa kegiatan promosi yang dilakukan Royal Sandwich sangat efektif karena promosi tersebut telah menarik perhatian dan dapat menambah pengetahuan serta pesan yang disampaikan dapat dimengerti responden sehingga mendorong mereka untuk melakukan pembelian produk Royal Sandwich. Selain itu daya tarik produk yang ditampilkan dengan kemasan dan varian rasa yang beraneka ragam membuat konsumen untuk melakukan pembelian berulang.

3. Hasil analisis tingkat efektivitas media promosi pada produk sandwich goreng merek Royal Sandwich berdasarkan dampak penjualan dengan menggunakan metode analisis regresi sederhana dan uji statistik (uji determinasi dan uji F) menunjukan bahwa biaya promosi berpengaruh signifikan secara bersama-sama terhadap volume penjualan Royal Sandwich.

\section{SARAN}

1. Kegiatan media promosi pada produk Royal Sandwich berdasarkan EPIC model sudah sangat efektif dalam menstimulasi terjadinya kesadaran (awareness), ketertarikan (interest), dan berakhir pada pembelian (purchase) yang dilakukan oleh konsumen sehingga perlu dipertahankan kinerja media promosi yang sudah dijalankan selama ini. Selain itu Royal Sandwich perlu mengembangkan media promosi offline seperti kedai sandwich, brosur, dll agar konsumen yang tidak menggunakan media online pun mengetahui tentang Royal Sandwich.

2. Penilai efektivitas terhadap promosi sebaiknya dilakukan secara kontinyu $( \pm 6$ bulan sekali) agar dapat dipantau hasil dari promosi yang telah diterapkan dan sebagai acuan untuk penetapan strategi promosi selanjutnya. Sehingga dapat selalu dilihat promosi mana yang paling efektif dimata konsumen.

\section{DAFTAR PUSTAKA}

Andri, Gus. 2012. Strategi Pemasaran Dan Efektivitas Periklanan Dengan

Menggunakan Metode Komunikasi, Empati, Persuasi Dan Dampak Pada

Perusahaan PT. Bhineka Lestari LTD [Jurnal]. Padang: Universitas Tamansiswa.

Aninah. 2010. Analisis Efektifitas Media Promosi Produk Herbal Pada Outlet

PT.Prima Agitech Nusantara [Skripsi]. Jakarta: UIN Syarif Hidayatullah.

Arbie, Rivani. 2013. Twitter Is Money. Jakarta: Mediakita.

Kennedy, John E dan Soemanagara, R.D. 2009. Marketing Comunication Taktik \& Strategi. Jakarta: PT. Bhuana Ilmu Populer.

Kotler, P dan Armstrong, Gary. 2004. Dasar-Dasar Pemasaran. Jakarta: PT. Indeks Kelompok Gramedia.

Kotler, Philip \& Keller. 2006. Manajemen Pemasaran, Edisi Dua Belas, Jilid 1. Jakarta: Indeks.

Kotler, Philip \& Keller. 2009. Manajemen Pemasaran, Edisi Tiga Belas, Jilid 2. Jakarta: Penerbit Erlangga. 
Lee, Monle dan Johnson, Carla. 2007. Prinsip - Prinsip Pokok Periklanan Dalam

Perspektif Global. Jakarta : Kencana Prenada Media Gru.

Margaretha, Indrie Grance. 2012. Efektivitas Penggunaan Akun Facebook Dan Twitter Dalam
Promosi Penayangan Program Acara Dahsyat Rcti Kepada Khalayak [Skripsi]. Jakarta: Universitas Mercu Buana.

* Alamat Korespondensi: mudatsir@uinjkt.ac.id 